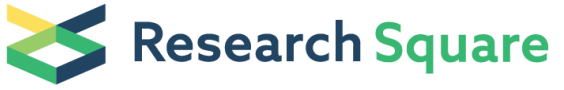 \\ Preprints are preliminary reports that have not undergone peer review. \\ They should not be considered conclusive, used to inform clinical practice, or referenced by the media as validated information.
}

\section{Inter-Laboratory Validation Of An ISO Test Method For Measuring Enzyme Activities In Soil Samples Using Colorimetric Substrates}

\author{
Nathalie Cheviron ( $\nabla$ nathalie.cheviron@inrae.fr ) \\ INRAE UMR1402 ECOSYS https://orcid.org/0000-0003-4395-4229
}

\section{Virginie Grondin}

INRAE Île-de-France-Versailles-Grignon: Institut National de Recherche pour l'Agriculture l'Alimentation et l'Environnement Centre lle-de-France-Versailles-Grignon

\section{Christelle Marrauld}

INRAE Île-de-France-Versailles-Grignon: Institut National de Recherche pour l'Agriculture l'Alimentation et l'Environnement Centre lle-de-France-Versailles-Grignon

\section{Francoise Poiroux}

INRAE Île-de-France-Versailles-Grignon: Institut National de Recherche pour l'Agriculture l'Alimentation et l'Environnement Centre lle-de-France-Versailles-Grignon

\section{Isabelle Bertrand}

INRAE Centre Occitanie-Montpellier: Institut National de Recherche pour l'Agriculture l'Alimentation et l'Environnement Centre Occitanie-Montpellier

\section{Josiane Abadie}

INRAE Centre Occitanie-Montpellier: Institut National de Recherche pour l'Agriculture l'Alimentation et l'Environnement

Centre Occitanie-Montpellier

\section{Pascal Pandard}

INERIS: Institut National de l'Environnement Industriel et des Risques

\section{Wassila Riah-Anglet}

UniLaSalle - Campus de Rouen

\section{Caroline Dubois}

UniLaSalle - Campus de Rouen

\section{Stanislav Maly}

Central Institute for Supervising and Testing in Agriculture

\section{Catarina R Marques}

University of Aveiro: Universidade de Aveiro

\section{Inmaculada Valverde Asenjo}

Complutense University of Madrid: Universidad Complutense de Madrid

\section{Alejandro Alonso}

Universidad Complutense de Madrid Facultad de Ciencias Biologicas

\section{Domingo Marquina Diaz}

Complutense University of Madrid: Universidad Complutense de Madrid

\section{Christian Mougin}

INRAE Île-de-France-Versailles-Grignon: Institut National de Recherche pour l'Agriculture I'Alimentation et l'Environnement Centre lle-de-France-Versailles-Grignon 


\section{Research Article}

Keywords: soil enzyme activities, soil functions, standardization, inter-laboratory trial, microplate test, soil quality

Posted Date: June 7th, 2021

DOI: https://doi.org/10.21203/rs.3.rs-517834/v1

License: (c) (i) This work is licensed under a Creative Commons Attribution 4.0 International License. Read Full License

Version of Record: A version of this preprint was published at Environmental Science and Pollution Research on November 25th, 2021. See the published version at https://doi.org/10.1007/s11356-021-17173-3. 


\section{Abstract}

The evaluation of soil quality requires the use of robust methods to assess biologically based-indicators. Among them, enzyme activities are used for several decades, but there is a clear need to update their measurement methods for routine use, in combining feasibility, accuracy and reliability. To this end, the platform Biochem-Env optimised a miniaturised method to measure enzyme activities in soils using colorimetric substrates in micro-well plates. The standardization of the method was carried out within the framework of ISO/TC 190/SC 4/WG 4 "Soil quality - Biological methods" workgroup, recommending an inter-laboratory evaluation for the publication of a full ISO standard.

That evaluation, managed by the platform, was based on the measurement, in six soils of contrasted physicochemical properties, of the ten soil enzyme activities described in the standard. Eight laboratories were involved in the validation study. Only $2.7 \%$ of outliers were identified from the analyses of the whole dataset. The repeatability and reproducibility of the method were determined by computing, respectively, the intra-laboratory $(\mathrm{CVr}$, ) and inter-laboratory (CVR) coefficients of variation for each soil and enzyme. The mean $\mathrm{CV}_{\mathrm{r}}$ ranged from 4.5\% (Phosphatase) to 9.9\% (aGlucosidase), illustrating a reduced variability of enzyme activities within laboratories. The mean $\mathrm{CV}_{\mathrm{R}}$ ranged from $13.8 \%$ (Alkaline Phosphatase) to 30.9\% (Phosphatase).

Nevertheless, the method was repeatable, reproducible and sensitive. It also proved to be applicable for measuring enzyme activities in different types of soils. These results have been found successful by ISO/TC 190/SC4 and resulted in the publication of ISO 20130:2018 standard.

\section{Introduction}

Soils are the nexus of water, energy and food, ensuring multiple functions and ecosystem services, as recently reviewed (Baveye et al. 2016). The use of biologically based-indicators, mainly linked to the abundance, as well as the metabolic diversity and activity of microorganisms, allows monitoring impacts on soil functions and services. Soil microorganisms are sensitive to agricultural practices, land use, contamination by chemicals, industrial and mining activities (Marques et al. 2014). Thus, soil enzyme activities, mainly from microorganism origin and/or immobilised within organic and inorganic colloids, are valuable tools used for several decades to evaluate soil quality (Philippot et al. 2012), or the efficiency of soil management or restoration measures.

The soil enzymes are the mediators of organic matter decomposition and soil biochemical transformations. Enzymes are integral part of the biogeochemical cycles, influencing major soil nutrients such as C, P, N, and S (Dick et al. 1996; Nannipieri et al. 2002). In soils, the production of enzyme can be either constitutive (routinely produced by cells) or adaptive (induced only in the presence of a substrate) (Baldrian 2014; Lagomarsino et al. 2009; Nannipieri et al. 2002). Considering their location, soil enzymes could be localized within cells (intracellular) or out of cells (extracellular) (Klose 2003; Wallenstein and Burns 2011). When extracellular enzymes are released in soil, they could subsequently be stabilized on the surface of clay minerals, or form copolymers with humic colloids and or organic matter (Burns et al. 2013; Wallenstein and Burns 2011). Enzymes lifetime and activities varied widely in soils and they are controlled by the interactions between substrate availability, the concentration of active enzymes (depending on their expression, their stabilization and their degradation), and the abiotic characteristics of the soils (Allison and Jastrow 2006; Burns et al. 2013; Dick and Tabatabai 1987; Quiquampoix and Burns 2007; Sinsabaugh et al. 2009). Soil enzymes mainly belong to hydrolases, oxidoreductases, transferases and lyases (Tabatabai and Dick 2002). Hydrolases are the most commonly measured class of enzymes in soils (Burns et al. 2013; Nannipieri et al. 2002, Trap et al. 2012; Riah et al. 2014). Enzymes respond to soil management changes before changes in other soil parameters are detectable. For that, several authors proposed the use of the patterns of enzyme activities in relation to environmental factors and management practices as an integrative indicator to provide information about soil state, and a valuable tool in helping to design sustainable 
management practices (Badiane et al. 2001; Bandick and Dick 1999; De la Paz Jimenez et al. 2002; Dotaniya et al. 2019; Floch et al. 2011; Riah-Anglet et al. 2015; Veum et al. 2014).

A relevant evaluation of soil quality requires the availability of robust measurement methods that combine feasibility, accuracy and reliability (repeatability and reproducibility). The potential automation of these biological methods is also important so that they can process a large number of samples. The literature concerning soil enzymology is extensive, and reports numerous approaches based on a similar principle but differing in experimental design, methods of detection (fluorometric or spectrometric), hence making difficult the comparison between the different data... Often based on different long-standing protocols, enzyme activity assays involve manual steps and can consume large amounts of reagents. Thus, their miniaturization into the microplate format has been performed for measuring soil enzyme activities in the 1990s (Wirth and Wolff 1992). Finally, the measured activities are also expressed using different units, which can limit cross-comparison of data between laboratories since recalculation is required. Hence, the need of method standardization has been highlighted for meaningful and appropriate data interpretation and comparison (Deng et al. 2017; Nannipieri et al. 2018). In this context, some initiatives were launched to identify promising methods to standardize for the analysis of soil functions (Thiele-Bruhn et al. 2020).

In that context, the platform Biochem-Env (Cheviron et al. 2018), a service of the research Infrastructure AnaEE-France (Clobert et al. 2018; Mougin et al. 2015) focuses on the development and measurement of biochemical indicators in the environments and organisms of continental ecosystems. It recently optimised a miniaturised method designed to measure enzyme activity patterns in soils using colorimetric substrates in micro-well plates. That methodological improvement allows a better biological characterization of soil quality. The standardization of the method has been developed within the framework of ISO/TC 190/SC 4/WG 4 "Soil quality - Biological methods - Effects on soil micro-organisms" with the support of the French mirror committee AFNOR T95E "Ecotoxicology" (Thiele-Bruhn et al. 2020). The method is intended to offer an alternative to that based on the use of fluorogenic substrates (ISO/TS 22939:2019), which are mainly conjugates of 4-methylumbelliferone (MUF). It has been shown that activities of different enzymes in diverse soils measured using MUF and colorimetric substrates were within the same order of magnitude and significantly correlated when assay conditions were carefully controlled (Deng et al. 2013; Dick et al. 2018). By contrast, Trap et al. (2012) showed that improved effectiveness and efficiency were obtained in measuring soil enzymes as universal soil quality indicators using microplate fluorimetry.

The aim of this study was to evaluate the variability and validate the proposed method of measurement using colorimetric substrates in micro-well plates, in its ISO/CD 20130 stage. To this end, an international inter-laboratory trial was carried out on ten enzyme activities in six different soil samples by eight research teams from four European countries.

\section{Materials And Methods}

Coordination and participants

The inter-laboratory trial was organized and coordinated by the staff of the platform Biochem-Env (Biochem-Env, 2019), involved in the ISO/TC 190/SC 4/WG 4 "Soil quality - Biological methods - Effects on soil micro-organisms" working group.

Eight laboratories from four countries were participating in the validation study (one for Czech Republic, one from Portugal, two from Spain, and four from France), and all belonged to research institutions.

The participating laboratory quantified the ten enzymatic activities in six soil samples, in triplicate for each sample. Laboratories were requested to follow the protocol updated after the first voting stage (committee draft ISO/CD 20130). 
A kick-off meeting has been held in Versailles in spring 2016 to present the interlaboratory trial, provide main documents and describe the protocol to be fulfilled. Electronic formatted spreadsheets (Excel ${ }^{T M}$ ) have also been sent to the participants to facilitate the data collection and analysis.

Soil samples

Meadow and arable soils were sampled from French experimental sites in France (Pierre Plate, INRAE Versailles; La Cage, INRAE Versailles; Lycée Agricole et Agroalimentaire Yvetot (provided by UniLaSalle, Rouen); Qualiagro, SOERE PRO, INRAEVeolia Recherche \& Innovation partnership, Feucherolles; Efele, SOERE PRO, INRAE Le Rheu; PROspective, SOERE PRO, INRAE Colmar). For the purpose of the ring-test and in order to minimize the influence of external factors, six soils were sampled in autumn 2015 by the platform staff from the surface soil layer $(0-20 \mathrm{~cm})$, immediately sieved through a 2-mm sieve and air dried for 8 days at room temperature. Aliquots (100 g dry weight) were sent by the platform staff to each participant, at room temperature. The selected soils covered a wide range of agropedoclimatic context in France. Their main properties (texture, $\mathrm{pH}$, organic carbon, Cation Exchange Capacity) and land use are reported in Table 1. The range of variation of these properties was consistent with cropped soils.

Table 1

Properties of the soils used in the inter-laboratory trial

\begin{tabular}{|c|c|c|c|c|c|c|c|c|c|c|}
\hline Soil & Site & $\begin{array}{l}\text { Soil } \\
\text { Nomenclature } \\
\text { (WRB 2015) }\end{array}$ & $\begin{array}{l}\text { Silt } \\
\%\end{array}$ & $\begin{array}{l}\text { Sand } \\
\%\end{array}$ & $\begin{array}{l}\text { Clay } \\
\%\end{array}$ & $\mathrm{pH}$ & $\begin{array}{l}\text { Organic } \\
\mathrm{C} \\
\%\end{array}$ & $\begin{array}{l}\text { Total } \\
\mathbf{N} \\
\%\end{array}$ & $\begin{array}{l}\text { CEC } \\
\mathrm{cmol}+/ \mathrm{kg}\end{array}$ & $\begin{array}{l}\text { Land } \\
\text { use }\end{array}$ \\
\hline 1 & Pierre Plate & $\begin{array}{l}\text { Luvic } \\
\text { cambisol/cambisol }\end{array}$ & 13.0 & 76.2 & 10.8 & 5.6 & 2.19 & 0.12 & 6.6 & meadow \\
\hline 2 & La cage & Luvisol & 56.2 & 27.1 & 16.7 & 7.4 & 1.00 & 0.10 & 11.5 & $\begin{array}{l}\text { arable } \\
\text { soil }\end{array}$ \\
\hline 3 & Yvetot & Neoluvisol-Luvisol & 63.5 & 19.7 & 16.8 & 5.5 & 2.57 & 0.25 & 8.1 & meadow \\
\hline 4 & Qualiagro & Luvisol & 78.3 & 6.70 & 15.0 & 6.6 & 1.05 & 0.10 & 7.9 & $\begin{array}{l}\text { arable } \\
\text { soil }\end{array}$ \\
\hline 5 & Efele & Luvisol-Redoxisol & 79.3 & 16,1 & 14.6 & 6.0 & 1.15 & 0.12 & 6.1 & $\begin{array}{l}\text { arable } \\
\text { soil }\end{array}$ \\
\hline 6 & PROspective & Calcasol & 66.5 & 9.6 & 23.4 & 8.5 & 1.43 & 0.12 & 16.9 & $\begin{array}{l}\text { arable } \\
\text { soil }\end{array}$ \\
\hline
\end{tabular}

Chemicals

All products were purchased from Sigma-Aldrich, subdivided by the platform staff and provided to the participants.

Solutions for use were prepared by each laboratory.

Measurement of enzymatic activities

Ten enzyme activities were measured in soil samples, most of them according to protocols modified from older ones (e.g. Tabatabai and Bremner 1970; Dick et al. 1996; Sinsabaugh et al. 2000): $\alpha$-glucosidase (aGLU, E.C. 3.2.1.20), $\beta$-glucosidase ( $\beta G L U$, E.C. 3.2.1.21), $\beta$-galactosidase ( $\beta G A L$, E.C. 3.2.1.23), acid phosphatase (ACP, E.C. 3.1.3.1), alkaline phosphatase (ALP, E.C. 3.1.3.2), phosphatase (PHOS, acid or alkaline according to the $\mathrm{pH}$ of soil solution), arylsulfatase (ARS, E.C. 3.1.6.1), N-acetyl-glucosaminidase (NAG, E.C. 3.2.1.52), arylamidase (ARN, E.C. 3.4.11.2) and urease (URE, E.C. 3.5.1.5). 
The analyses were carried out, in triplicate. Soil suspensions were prepared by mixing $4 \mathrm{~g}$ (dry weight) of soil with $25 \mathrm{~mL}$ of deionized water (for ARS, aGLU, $\beta G L U, \beta G A L, N A G, P H O S$ and URE), $50 \mathrm{mM}$ Tris base $\mathrm{pH} 7.5$ (for ARN); $50 \mathrm{mM} \mathrm{Tris} \mathrm{HCl}$ $\mathrm{pH} 5.5$ (for ACP) or $50 \mathrm{mM}$ Tris base $\mathrm{pH} 11$ (for ALP) into flat-bottom plastic flasks (30-60 mL). They were then homogenized for $10 \mathrm{~min}$ on an orbital agitator $\left(250 \mathrm{~min}^{-1}\right)$ and maintained under stirring during suspension pipetting into 96-well microplates.

Soil suspensions pipetted from each flask ( $125 \mu \mathrm{L}$ for all activities and $50 \mu \mathrm{L}$ for URE) were separately distributed in four replicate wells. One of the wells was used as a control to reveal the influence of chemical interactions between soil compounds in the spectrometric readings.

According to the enzyme, the substrates added to the corresponding wells were: $25 \mu \mathrm{L}$ of $8 \mathrm{mM}$ L-leucine $\beta$ naphthylamide hydrochloride for ARN, $25 \mu \mathrm{L}$ of $25 \mathrm{mM}$ potassium $p$-nitrophenyl sulphate for ARS, $25 \mu \mathrm{L}$ of $50 \mathrm{mM} p$-nitrophenyl $\beta$-Dgalactopyranoside for $\beta G A L, 25 \mu \mathrm{L}$ of $25 \mathrm{mM} p$-nitrophenyl $a$-D-glucopyranoside for aGLU, $25 \mu \mathrm{L}$ of $10 \mathrm{mM} p$-nitrophenyl $\mathrm{N}$-acetyl $\beta$-D glucopyranoside for $\beta \mathrm{GLU}, 25 \mu \mathrm{L}$ of $50 \mathrm{mM} p$-nitro-phenylphosphate disodium salt hexahydrate for PHOS, ACP and ALP, and $40 \mu \mathrm{L}$ of $400 \mathrm{mM}$ urea for URE. Deionized water $(150 \mu \mathrm{L}$ in assay wells and $190 \mu \mathrm{L}$ in control wells) was also added for URE.

The incubation conditions were: $30 \mathrm{~min}$ at $37^{\circ} \mathrm{C}$ for PHOS, PAC and PAK; 60 min at $37^{\circ} \mathrm{C}$ for aGLU and $\beta G L U ; 120$ min at $37^{\circ} \mathrm{C}$ for NAG, ARN and $\beta G A L ; 180 \mathrm{~min}$ at $25^{\circ} \mathrm{C}$ for URE; $240 \mathrm{~min}$ at $37^{\circ} \mathrm{C}$ for ARS.

Reactions were stopped for ARS, $\beta G A L, a G L U, \beta G L U, N A G, P H O S, A C P$ and ALP by adding $25 \mu L$ of $500 \mathrm{mM}$ calcium chloride in the assay wells; and $100 \mu \mathrm{L}$ of $100 \mathrm{mM}$ Tris base buffer $\mathrm{pH} 12$ plus $25 \mu \mathrm{L}$ of the appropriate substrate in the respective enzyme control well. The plates were afterwards centrifuged for 5 minutes at $1,500 \mathrm{~g}$ and $20^{\circ} \mathrm{C}$, and $200 \mu \mathrm{L}$ of the supernatant was transferred into a new plate. The absorbance of the reaction product, $p$-nitrophenol, was measured in a microplate spectrophotometer UV/visible at $\lambda=405 \mathrm{~nm}$, being its concentration determined from a $p$-nitrophenol calibration curve ( $c f$. supporting information for further details).

For ARN, $150 \mu \mathrm{L}$ ethanol $96 \%$ was added to each well including controls, and $25 \mu \mathrm{L}$ of substrate solution was added into control wells. The plates were centrifuged 5 minutes at $1,500 \mathrm{~g}$ and $100 \mu \mathrm{L}$ of supernatant was transferred into a new plate. To reveal the quantity of $\beta$ naphthylamine produced, $100 \mu \mathrm{L}$ of acidic ethanol and $100 \mu \mathrm{L}$ of $3.5 \mathrm{mM} p$ dimethylaminocinnamaldehyde were added in all wells. After $20 \mathrm{~min}$, the reading of absorbance was performed in a microplate spectrophotometer UV/visible at $\lambda=540 \mathrm{~nm}$, and the $\beta$ naphthylamine concentration was determined from a $\beta$ naphthylamine calibration curve.

For URE, $40 \mu \mathrm{L}$ of salicylate reagent was added to each well, including controls. Salicylate reagent was prepared just before analysis by dissolving $865 \mathrm{mg}$ of sodium salicylate, $853 \mathrm{mg}$ of trisodium citrate, $276 \mathrm{mg}$ of disodium tartrate and $12 \mathrm{mg}$ of sodium nitroferricyanide in $20 \mathrm{~mL}$ of deionized water. After a 3 min period, $40 \mu \mathrm{L}$ of cyanurate reagent was dispensed into each well, including controls. Cyanurate reagent was prepared just before analysis by dissolving $3.4 \mathrm{~g}$ of trisodium citrate, $414 \mathrm{mg}$ of disodium tartrate, $134 \mathrm{mg}$ of lithium hydroxide and $51 \mathrm{mg}$ of dichloroisocyanurate in $20 \mathrm{~mL}$ of deionized water. Colorimetric reaction was achieved after $30 \mathrm{~min}$, being stable for two hours. The plates were then centrifuged 5 minutes at $1,500 \mathrm{~g}$ and $20^{\circ} \mathrm{C}$, and $200 \mu \mathrm{L}$ of the supernatant was transferred into a new plate. The reading of absorbance was performed with a microplate spectrophotometer UV/visible at $\lambda=650 \mathrm{~nm}$, and concentration determined from an ammonium chloride calibration curve.

Enzyme activities were expressed in $\mathrm{mU} \mathrm{g}^{-1}$ dry soil, corresponding to nmole of $p$-nitrophenol, $\beta$-naphthylamine or ammonium chloride released per minute and per $\mathrm{g}$ of dry soil.

\section{Statistical Analysis}


All analyses were performed using R-project software (The R Development Core Team, Ri386 3.5.0). Results are expressed as mean \pm SD (standard deviation) and CV (coefficient of variation). Coherence check was ensured by identifying outlier data using the Grubbs test $(P<0.05)$ package "outliers" (Komsta 2011).

The intra-laboratory coefficient of variation (repeatability, $\mathrm{CV}_{\mathrm{r}}$ ) and inter-laboratory coefficient of variation (reproducibility, $\mathrm{CV}_{\mathrm{R}}$ ) were calculated as described below from enzyme activities. They were considered acceptable by the ISO TC190/SC4 when the CV values were below $30 \%$.

$C V_{r}=\sum_{i=1}^{L}\left(\frac{s_{i}}{x_{i}}\right) \times \frac{100}{L}$

$\mathrm{CV}_{\mathrm{r}}$ is the repeatability coefficient of variation; $S_{i}$ is the repeatability standard deviation calculated from intra-laboratory data; $X_{i}$ is the mean of values calculated from intra-laboratory data; $L$ is the number of the participating laboratory.

$$
C V_{R}=\frac{s_{R}}{X} \times 100
$$

$\mathrm{CV}_{\mathrm{R}}$ is the reproducibility coefficient of variation; $S_{R}$ is the reproducibility standard deviation calculated from interlaboratory data; $X$ is the mean of values calculated from inter-laboratory data.

The comparison of the data provided by the laboratories for each soil were compared with PCA using the package ADE-4 (http://pbil.univ-lyon1.fr/ADE-4/home.php).

\section{Results}

\section{Calibration curves}

The equations of calibration curves have been computed from the application of linear regression to each of the three reaction products, $p$-nitrophenol, $\beta$-naphthylamine and ammonium chloride. The curves have been performed 3 to 10 times, depending to the laboratory (cf. supporting information for further details). Table 2 reports the characteristics of the three calibration curves. The slope and coefficients of variation have been calculated for each of the eight labs, and averaged. The three curves were linear with global $r^{2}$ value of 1.000 . The coefficient of variation of the slopes were $6.20 \%$ for $p$-nitrophenol and ammonium chloride, and $13.54 \%$ in the case of $\beta$-naphthylamine. Whatever the laboratories, these results showed, in the case $p$-nitrophenol, a high linearity and accuracy with a maximum CV value of $\cong 13 \%$ at concentrations $\leq 29 \mu \mathrm{M}$, and a CV $\leq 5 \%$ above that concentration (Table S1). In addition, the method showed a very high inter-laboratory reproducibility since the $\mathrm{CV}$ was $\leq 10 \%$ irrespectively of $p$-nitrophenol concentration. For $\beta$-naphthylamine, a high repeatability was obtained given that the $\mathrm{CV}_{\mathrm{r}}$ 's were $\leq 10 \%$, as well as a high reproducibility between laboratories was noticeable by the $\mathrm{CV}_{\mathrm{R}}$ 's of $\leq 22 \%$ in all concentrations (Table S2). The higher variability noticed at $10 \mu \mathrm{M}$ was once again explained for being close to the limit of quantification (LOQ) of the method. Concerning ammonium chloride, the repeatability was also very high with low intra-laboratory variability, $\mathrm{CV}_{\mathrm{r}} \leq 6 \%$. The higher variability $\left(\mathrm{CV}_{\mathrm{r}} \cong 13 \%\right)$ at $6 \mu \mathrm{M}$ was indeed associated to the proximity to the LOQ. The analysis of the inter-laboratory variability reinforced the high reproducibility of the assay (CV $\leq 20 \%)$ (Table S3).

Table 2. Parameters of the calibration curves for $p$-nitrophenol, $\beta$ naphthylamine and ammonium chloride 


\begin{tabular}{|lllll|}
\hline Compound & \multicolumn{3}{l}{ Slope } & \multicolumn{2}{c|}{$\mathrm{r}^{2}$} \\
\cline { 2 - 5 } & Mean & SD & $\% \mathrm{CV}$ & \\
\hline$p$-nitrophenol & 0.0049 & 0.0003 & 6.20 & 1.000 \\
\hline$\beta$-naphthylamine & 0.011 & 0.002 & 13.54 & 1.000 \\
\hline ammonium chloride & 0.0049 & 0.0003 & 6.20 & 1.000 \\
\hline
\end{tabular}

Mean: mean of the directory coefficients of the 8 laboratories; SD: standard deviation; CV: coefficient of variation; $r^{2}$ : regression coefficient

Enzyme activity measurement in soils

All the laboratories performed the measurements of the ten enzyme activities in the six soil samples. The variation of the enzymes activities, with respect to soils and laboratories, are shown in Fig. 1. Data resulting from experimental errors, and all the data of one laboratory, which were totally outside the range of values obtained by the participating laboratories, were removed from the analyses. The complete dataset of the interlaboratory trial is provided as supporting information (cf the link above mentioned).

The inter-laboratory trial generated highly satisfactory results regarding the feasibility, accuracy, repeatability and reproducibility of the measurement method of enzyme activity, for all soil types considered. Overall, only $2.7 \%$ of outliers data (11/411) have been identified in the whole dataset using the Grubbs test. These were due to problems affecting analytical performance within the laboratories and were not attributable to the method (error of wave length or protocole used, noticed by laboratories themselves). Despite these outliers, the results generated by the laboratories for the different soils could be compared, as long as the same method was used.

The mean $\mathrm{CV}_{\mathrm{r}}$ ranged from 4.5\% (PHOS) to $9.9 \%$ (aGLU), illustrating a reduced variability on the enzyme activities within laboratories (Fig. 2A). Figure $2 \mathrm{~B}$ shows $\mathrm{CV}_{\mathrm{R}}$, the inter-laboratory coefficient of variation (reproducibility). The variability analyzed for each enzyme, considering the soils altogether, evidenced a mean $C_{R}$ ranged from $13.8 \%$ (ALP) to $30.9 \%$ (PHOS), illustrating a heterogeneous variability of the enzymes activity measurement methods. $\beta$ GAL and PHOS exhibited the highest variations $\left(C V_{R} \approx 30 \%\right)$, followed by $A R N$ and $A R S\left(C V_{R} \approx 20 \%\right)$. For all other enzymes activities, the $C V_{R}$ were below $20 \%$, suggesting a greater reproducibility of the measurement method. Concerning the overall variability within each soil (mean of $\mathrm{CV}_{\mathrm{R}}$ for 10 enzymatic activities; supplementary information), we can notice that soils 2 and 5 provided the highest dispersion ( $C V_{R}$ mean of $21.3 \%$ and $22.5 \%$ respectively). Such variation doesn't seem correlated with soil use nor with its physicochemical characteristics. We were unable to rely that variability to a particular laboratory throughout the study (Fig. 1 and supplementary information), even if a single laboratory seemed to impact the most variable enzymes.

The data provided by the laboratories for each soil have been compared by PCA (Fig. 3). The soils are distributed into four separate groups, i.e., Soil 3 , Soil 6 , Soils $2 / 4$, Soils $1 / 5$ ). This analysis shows that inter-laboratory variability does not affect the classification of most of the soils regarding the level of activities. For soils without statistical difference in activity (soils $2 / 4$ and soils $1 / 5$ ), the range could be different, but without any significance.

\section{Discussion}

Here we present and discuss the results obtained during the inter-laboratory evaluation of the method supporting the ISO standard 20130 "Soil quality - Measurement of enzyme activity patterns in soil samples using colorimetric substrates in micro-well plates". The measurements carried out on ten enzyme activities in six different soil samples by eight laboratories from four European countries proved that the method is highly repeatable and reproducible. 
Several major points can be highlighted.

1) The overall results indicated that the method was easy to implement and perform. Only $2.7 \%$ of outlier data and some missing data were obtained. As far as we know, these problems were due to errors in the protocol $(\lambda, \mathrm{pH})$ within the laboratories, and were not related to the method itself.

2) This method is relevant for analyzing agricultural soils exhibiting diverse physicochemical parameters, origin or use. Following the inter-laboratory evaluation of the method, the ISO 20130 was applied to characterize 726 soils sampled by the French RMQS ("Réseau de Mesures de la Qualité des Sols"). No limitation in the applicability of the protocol was identified. The range of activity of each enzyme is very large and quantifiable using this method. For example, the biggest response interval is for PHOS activity, ranged from 0.92 to $200.3 \mathrm{mU} \mathrm{g}^{-1}$ of dry soil (unpublished result).

3) In our experimental conditions, the sensitivity of the method based on colorimetric substrates is quite sufficient for enzyme measurement in soils. Low LOQ can be achieved for assays based on the detection of $p$-nitrophenol $(0.7 \mathrm{nmol})$, $\beta$ naphthylamine $(4 \mathrm{pmol})$ and ammonium chloride $(0.2 \mathrm{nmol})$. In the case of $p$-nitrophenol detection, the LOQ is 23 -time lower than the reported by Deng et al. (2013) in the $p$-nitrophenol-bench assay. The limits of quantification were $2 \mathrm{nmol}$ for $p$-nitrophenol, $11 \mathrm{pmol}$ for $\beta$ naphthylamine and $0.5 \mathrm{nmol}$ for ammonium chloride. These low values suggest that our method is sensitive enough to perform assays in soils with relatively low enzyme activities, although the higher variability at lower $p$-nitrophenol concentrations was explained by the closeness to the limits of quantification. Moreover, the robustness of the method allows increasing soil quantity or time of incubation, in case of soils with very low enzymatic activity (details of validation provided in ISO standard).

4) The within- and between-lab variability of the method are globally low: respectively $<10 \%$ for $\mathrm{CV}_{\mathrm{r}}$ and $13.8-30.9 \%$ for $\mathrm{CV}_{\mathrm{R}}$. These variability does not affect the classification of soils regarding the level of activities.

5) The standardization of the method is suitable for different uses, including manual measurements but also automated platforms with a multi-probe head. This process will increase the trueness and precision (repeatability and reproducibility) of the measurements, as well as their throughput in a context of large series of samples.

6) The proposal of a new standardized method will make easier cross-comparison of the data between laboratories, development of reference tools for assessing soil quality, further develop existing reference guides of enzymatic activities with standardized data.

\section{Conclusions}

Interlaboratory studies are efficient tools to demonstrate that enzymatic methods are suitable to evaluate soil quality (Marques et al. 2028). Here, we demonstrate that measurement of enzyme activity patterns in soils using colorimetric substrates in micro-well plates can be routinely used. All the participants successfully accessed the methodology within a brief period and fulfilled the validity criteria with a high degree, demonstrating that the method was repeatable and reproducible. It is efficient to measure enzyme activities in soils exhibiting contrasted properties, with high sensitivity, repeatability and reproducibility. The results of the inter-laboratory trial has been evaluated by both the AFNOR T95E and the ISO/TC 190/SC 4/WG 4 experts and approved. The 20130:2018 standard, published afterwards, will make easier our ability of determining and interpreting results concerning soil functioning and microbiological parameters. It will be of immediate and unquestionable value in the context of multi-stakeholder research and monitoring programs.

\section{Declarations}

Acknowledgements

Page $9 / 15$ 
The authors would like to thank all the people who contributed to this project, particularly Sébastien Louis-Rose from AFNOR as manager of the committee T95E, and Antonio Bispo from INRAE (formerly at ADEME), for their important support and precious advices. Biochem-Env (https://doi.org/10.15454/HA6V6Y) is a service of the "Investissement d'Avenir" infrastructure AnaEE-France. The department ECOSYS is member of the LabEx BASC, funded by "Investissement d'Avenir" Program overseen by the French National Research Agency (ANR) (LabEx BASC, ANR-11-LABX-0034), and member of the Federation Ile-de-France of Research for the Environment (FR 3020 FIRE).

Funding

The study was funded by ADEME (Agence de l'Environnement et de la Maîtrise de l'Energie, grant N¹960C0096) in France. Catarina R. Marques was funded by national funds (OE), through FCT - Fundação para a Ciência e a Tecnologia, I.P., in the scope of the framework contract foreseen in the numbers 4, 5 and 6 of the article 23, of the Decree-Law 57/2016, of August 29, changed by Law 57/2017 of July 19. AnaEE-France is overseen by the French National Research Agency (ANR) (ANR-11-INBS-0001).

Data availability

All data, as well as supporting information, are currently available on https://data.inrae.fr/privateurl.xhtml? token=26dbb81c-a70d-468b-a72e-6704316eaa31

NB: Data will be fully open after the acceptance of the manuscript.

Authors contributions

Nathalie Cheviron, Virginie Grondin and Christian Mougin were responsible for the design of the present study. Nathalie Cheviron and Christian Mougin prepared and wrote the original draft. Nathalie Cheviron and Virginie Grondin curated the data and performed the statistical analyses. All co-authors performed the experiments, acquired and provided the data, reviewed the manuscript and approved the final version.

Ethical approval: not applicable

Consent to participate: not applicable

Consent to publish: not applicable

Competing interests: the authors declare they have no competing interests.

\section{References}

1. Allison SD, Jastrow JD (2006) Activities of extracellular enzymes in physically isolated fractions of restored grassland soils. Soil Biol Biochem 38:3245-3256. https://doi.org/10.1016/j.soilbio.2006.04.011

2. Badiane NNY, Chotte JL, Pate E, Masse D, Rouland C (2001) Use of soil enzyme activities to monitor soil quality in natural and improved fallows in semi-arid tropical regions. Appl Soil Ecol 18:229-238. https://doi.org/10.1016/S0929-1393(01)00159-7

3. Baldrian P (2014) Distribution of Extracellular Enzymes in Soils: Spatial Heterogeneity and determining Factors at Various Scales. Soil Sci Soc Am J 78:11-18. https://doi.org/10.2136/sssaj2013.04.0155dgs

4. Bandick AK, Dick RP (1999) Field management effects on soil enzyme activities. Soil Biol Biochem 31:1471-1479. https://doi.org/10.1016/S0038-0717(99)00051-6

5. Baveye PC, Baveye J, Gowdy J (2016) Soil "ecosystem" services and natural capital: critical appraisal of research on uncertain ground. Front Environ Sci 4:41. https://doi.org/10.3389/fenvs.2016.00041

Page 10/15 
6. Biochem-Env (2019) INRAE, Platform of Environmental Biochemistry, https://doi.org/10.15454/HA6V6Y

7. Burns RG, DeForest JL, Marxsen J, Sinsabaugh RL, Stromberger ME, Wallenstein MD, Weintraub MN, Zoppini A (2013) Soil enzymes in a changing environment: current knowledge and future directions. Soil Biol Biochem 58:216-234. https://doi.org/10.1016/j.soilbio.2012.11.009

8. Cheviron N, Grondin V, Mougin C (2018) Biochem-Env: a platform of biochemistry for research in environmental and agricultural sciences. Environ Sci Pollut Res 25:6154-6157. https://doi.org/10.1007/s11356-017-8973-x

9. Clobert J, Chanzy A, le Galliard J-F, Chabbi A, Greiveldinger L, Caquet T, Loreau M, Mougin C, Pichot C, Roy J, SaintAndré L (2018) How to integrate experimental research approaches in ecological and environmental studies: AnaEE France as an example. Front Ecol Evol 6:43. https://doi.org/10.3389/fevo.2018.00043

10. De la Paz Jimenez M, de la Horra AM, Pruzzo L, Palma RM (2002) Soil quality: a new index based on microbiological and biochemical parameters. Biol Fert Soils 35:302-306. https://doi.org/10.1007/s00374-002-0450-z

11. Deng SP, Popova IE, Dick L, Dick RP (2013) Bench scale and microplate format assay of soil enzyme activities using spectrometric and fluorometric approaches. Appl Soil Ecol 64:84-90. https://doi.org/10.1016/j.apsoil.2012.11.002

12. Deng S, Dick R, Freeman C, Kandeler E, Weintraub MN (2017) Comparison and standardization of soil enzyme assay for meaningful data interpretation. J Microbiol Met 133:32-34. https://doi.org/1016/j.mimet.2016.12.013

13. Dick RP, Breakwell DP, Turco RF (1996) Soil enzyme activities and biodiversity measurements as integrative microbiological indicators. In: Doran DW, Jones AJ (eds) Methods for assessing soil quality, vol 9. Soil Science Society of America, Madison, pp 9-17

14. Dick RP, Dick LK, Deng S, Li X, Kandeler E, Poll C, Freeman C, Graham Jones T, Weintraub MN, Esseili KA, Saxena J (2018) Cross-laboratory comparison of fluorimetric microplate and colorimetric bench-scale soil enzyme assays. Soil Biol Biochem 121:240-248. https://doi.org/10.1016/j.soilbio.2017.12.020

15. Dick RP, Tabatabai MA (1987) Factors affecting hydrolysis of polyphosphates in soils. Soil Sci 143:97-104

16. Dotaniya ML, Aparna K, Dotaniya CK, Singh M, Regar KL (2019) Role of Soil Enzymes in Sustainable Crop Production. In: Kuddus M (ed) Enzymes in Food Biotechnology. Academic Press, Chap. 33, pp 569-589

17. Floch C, Chevremont AC, Joanico K, Capowiez Y, Criquet S (2011) Indicators of pesticide contamination: soil enzyme compared to functional-diversity of bacterial communities via Biolog Ecoplates. Eur J Soil Biol 47:256.263. https://doi.org/10.1016/j.ejsobi.2011.05.007

18. ISO 20130:2018. Soil quality - Measurement of enzyme activity patterns in soil samples using colorimetric substrates in micro-well plates

19. ISO/TS 22939:2019. Soil quality - Measurement of enzyme activity patterns in soil samples using fluorogenic substrates in micro-well plates

20. Klose S (2003) Enzyme Mediated Reactions and Microbial Biomass in Agricultural and Fly Ash Influenced Forest Ecosystems. Habilitation dissertation Dresden University of Technology, Germany

21. Komsta L (2011) Package 'outliers'; URL http://www.r-project.org, http://www.komsta.net/. Accessed 21 september 2020

22. Lagomarsino A, Moscatell MC, Di Tizio A, Mancinelli R, Grego S, Marinari S (2009) Soil biochemical indicators as a tool to assess the short-term impact of agricultural management on changes in organic $\mathrm{C}$ in a Mediterranean environment. Ecol Indic 9:518-527. https://doi.org/10.1016/j.ecolind.2008.07.003

23. Mougin C, Azam D, Caquet T, Cheviron N, Dequiedt S, Le Galliard JF, Guillaume O, Houot S, Lacroix G, Lafolie F, Maron PA, Michniewicz R, Pichot C, Ranjard L, Roy J, Zeller B, Clobert J, Chanzy A (2015) A coordinated set of ecosystem research platforms open to international research in ecotoxicology, AnaEE-France. Environ Sci Pollut Res 22(20):16215-16228. https://doi.org/10.1007/s11356-015-5233-9

Page $11 / 15$ 
24. Marques CR, Caetano AL, Haller A, Goncalves F, Pereira R, Rombke J (2014) Toxicity screening of soils from different mine areas-A contribution to track the sensitivity and variability of Arthrobacter globiformis assay. J Hazard Mat 274:331-341. https://doi.org/10.1016/j.jhazmat.2014.03.066

25. Marques CR, El-Azhari N, Martin-Laurent F, Pandard P, Meline C, Petre AL, Eckert S, Zipperle J, Vana M, Maly S, Sindelarova L, Amemori AS, Hofman J, Kumar A, Doan H, McLaughlin M, Richter E, Rombke J (2018) A bacteriumbased contact assay for evaluating the quality of solid samples Results from an international ring-test. J Hazard Mat 352:139-147. https://doi.org/10.1016/j.jhazmat.2018.03.022

26. Nannipieri P, Kandeler E, Ruggiero P (2002) Enzyme activities and microbiological and biochemical processes in soil. In: Burns RG, Dick R (eds) Enzymes in the Environment. Marcel Dekker, New York, pp 1-33

27. Nannipieri P, Trasar-Cepeda C, Dick RP (2018) Soil enzyme activity: a brief history and biochemistry as a basis for appropriate interpretations and meta-analysis. Biol Fertil Soils 54:11-19. https://doi.org/10.1007/s00374-017-1245-6

28. Philippot L, Ritz K, Pandard P, Hallin S, Martin-Laurent F (2012) Standardisation of methods in soil microbiology: progress and challenges. FEMS Microbiol Ecol 82(1):1-10. https://doi.org/10.1111/j.1574-6941.2012.01436.x

29. Quiquampoix H, Burns RG (2007) Interactions between proteins and soil mineral surfaces: environmental and health consequences. Elements 3:401-406. https://doi.org/10.2113/GSELEMENTS.3.6.401

30. Riah-Anglet W, Trinsoutrot-Gattin I, Martin-Laurent F, Laroche-Ajzenberg E, Norini M-P, Latour X, Laval K (2015) Soil microbial community structure and function relationships: A heat stress experiment. Appl Soil Ecol 86:121-130. https://doi.org/10.1016/j.apsoil.2014.10.001

31. Riah W, Laval K, Laroche-Ajzenberg E, Mougin C, Latour X, Trinsoutrot-Gattin I (2014) Effects of pesticides on soil enzymes: a review. Environ Chem Letters 12(2):257-273. https://doi.org/10.1007/s10311-014-0458-2

32. Sinsabaugh RL, Reynolds H, Long TM (2000) Rapid assay for amidohydrolase (urease) activity in environmental samples. Soil Biol Biochem 32(14):2095-2097. https://doi.org/10.1016/S0038-0717(00)00102-4

33. Sinsabaugh RL, Hill BH, Follstad Shah JJ (2009) Ecoenzymatic stoichiometry of microbial organic nutrient acquisition in soil and sediment. Nat Rev Microbiol 462:795-799. https://doi.org/10.1038/nature08632

34. Tabatabai MA, Bremner JM (1970) Arylsulfatase activity in soils. Soil Soc Sci Am Proc 34:225-229. https://doi.org/10.2136/sssaj1970.03615995003400020016x

35. Tabatabai MA, Dick WA (2002) Enzymes in soil: research and developments in measuring activities. In: Burns RG, Dick RP (eds) Enzymes in the Environment: Activity, Ecology, and Applications. Marcel Dekker, New York, pp 567-596

36. Thiele-Bruhn S, Schloter M, Wilke B-M, Beaudette LA, Martin-Laurent F, Cheviron N, Mougin C, Römbke J (2020) Identification of new microbial functional standards for soil quality assessment. Soil 6:17-34.

https://doi.org/10.5194/soil-6-17-2020

37. Trap J, Riah W, Akpa-Vinceslas M, Bailleul C, Laval K, Trinsoutrot- Gattin I (2012) Improved effectiveness and efficiency in measuring soil enzymes as universal soil quality indicators using microplate fluorimetry. Soil Biol Biochem 45:98-101. https://doi.org/10.1016/j.soilbio.2011.10.010

38. Veum KS, Goyne KW, Miles RJ, Sudduth KA (2014) Biological indicators of soil quality and soil organic matter characteristics in an agricultural management continuum. Biogeochemistry 117:81-99.

https://doi.org/10.1007/s10533-013-9868-7

39. Wallenstein MD, Burns RG (2011) Ecology of extracellular enzyme activities and organic matter degradation in soil: a complex community-driven process. In: Dick RP (ed) Methods of Soil Enzymology. Soil Science Society of America, Madison, pp 35-55

40. Wirth SJ, Wolff GA (1992) Micro-plate colourimetric assay for endo-acting cellulase, xylanase, chitinase, 1,3-[beta]glucanase and amylase extracted from forest soil horizons. Soil Biol Biochem 24:511-519.

https://doi.org/10.1016/j.mimet.2016.12.013

Page 12/15 
41. WRB IWG. World Reference Base for Soil Resources, International Soil Classification System for Naming Soils and Creating Legends for Soil Maps, Update 2015.World Reference Base for Soil Resources, International Soil Classification System for Naming Soils and Creating Legends for Soil Maps, Update 2015. World Soil Resources Reports No. 106. Reports, W.S.R., FAO, Roma

\section{Figures}

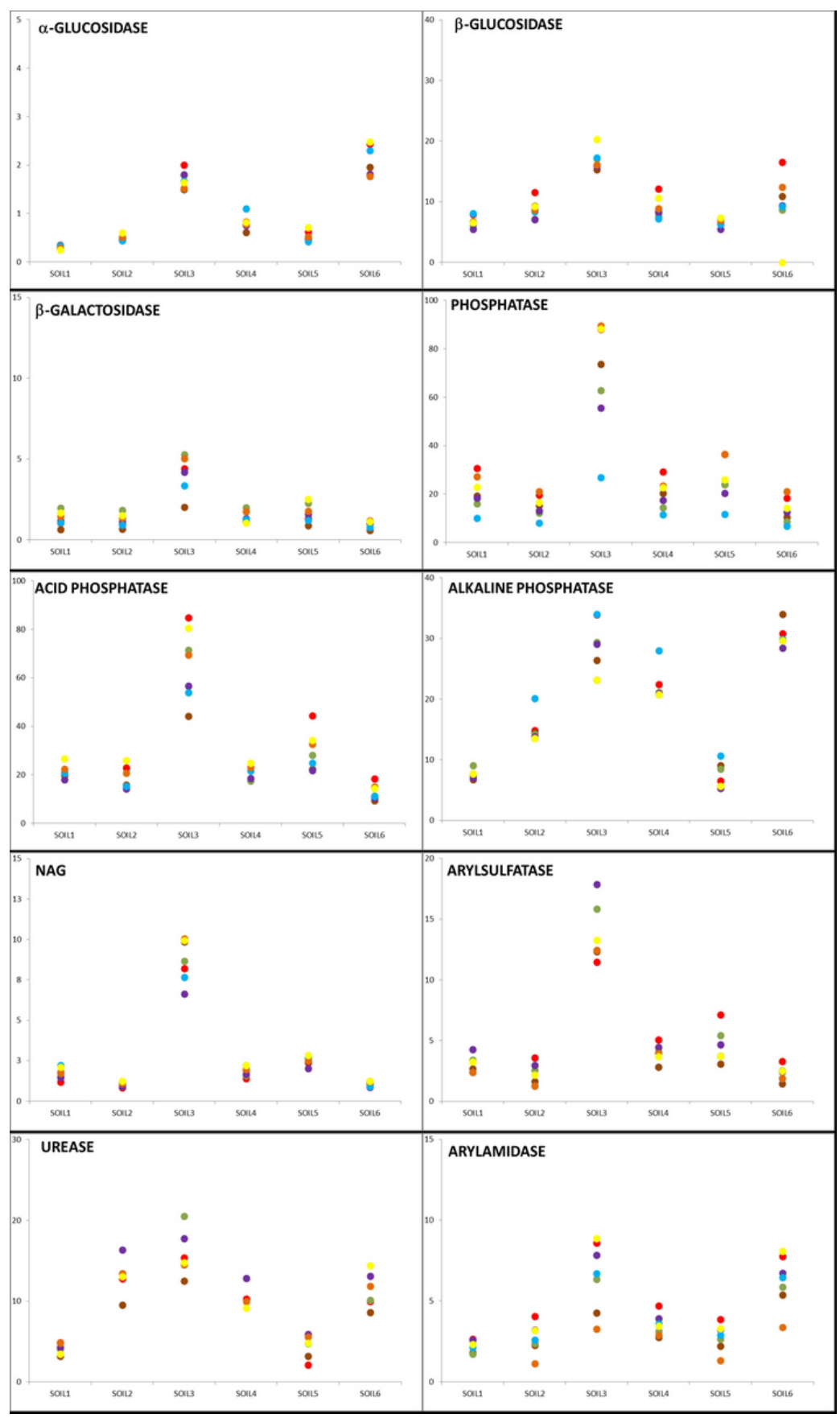

\section{Figure 1}

Variation of the 10 enzyme activities in 6 soils obtained by the 7 laboratories. Each colored point represents the mean calculated by laboratory (colors of dots are: lab 1 - red; lab 2 - brown; lab 3 green; lab 4 - purple; lab 5 - blue; lab 6 - orange; lab 7 - yellow). Activities (y-axis) are expressed in $\mathrm{mU} \mathrm{g-1}$ dry soil. Outliers and data resulting from experimental error were omitted. 
A

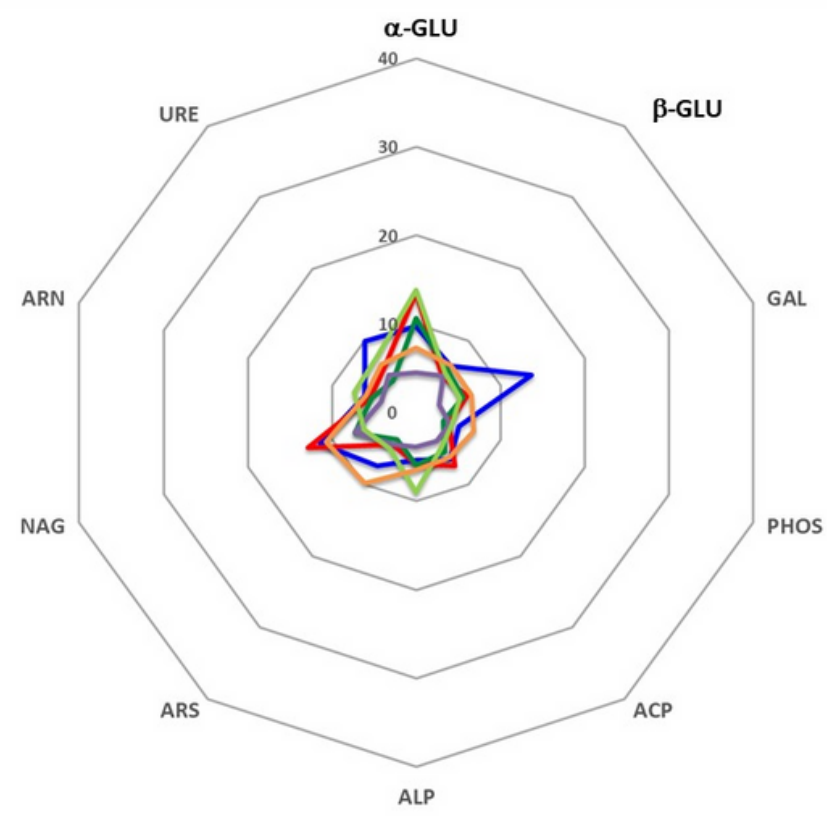

B

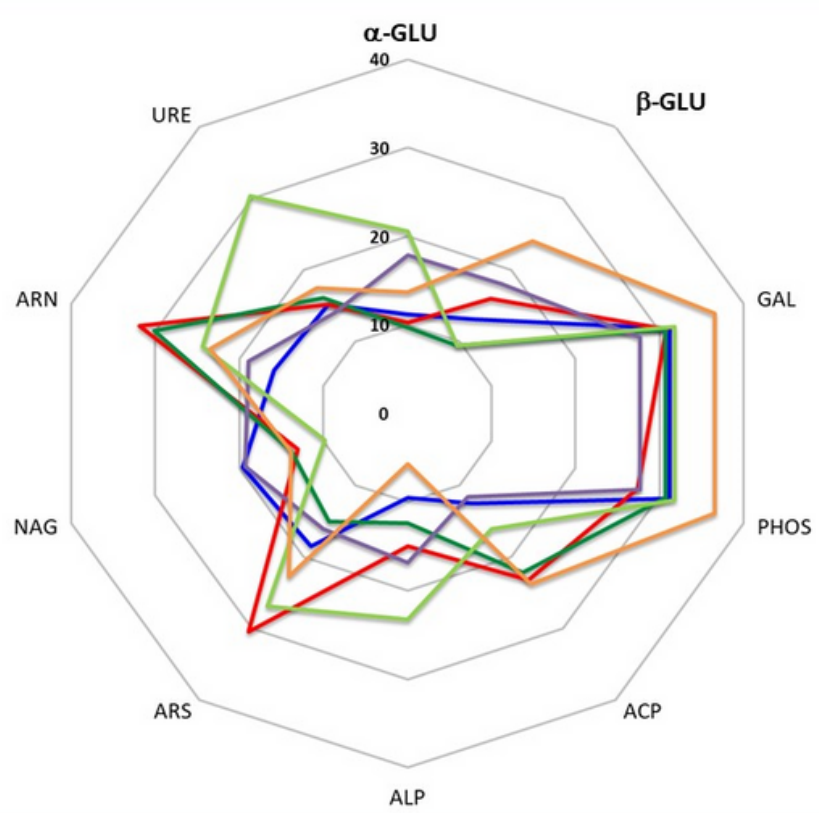

Figure 2

Intra (A) and inter (B) laboratory variability (represented by CV (\%) values) of soil enzymes activities measured for each

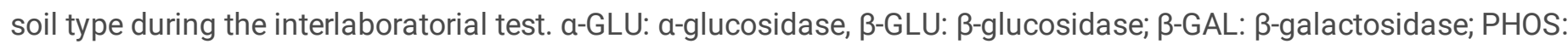
phosphatase; ACP: acid phosphatase; ALP: alkaline phosphatase; ARS: arylsulfatase; NAG: N-acetyl-glucosaminidase; ARN: arylamidase; URE: urease. Blue line: soil 1; red line: soil 2; dark green line: soil 3; purple line: soil 4; light green line: soil 5; orange line: soil 6.

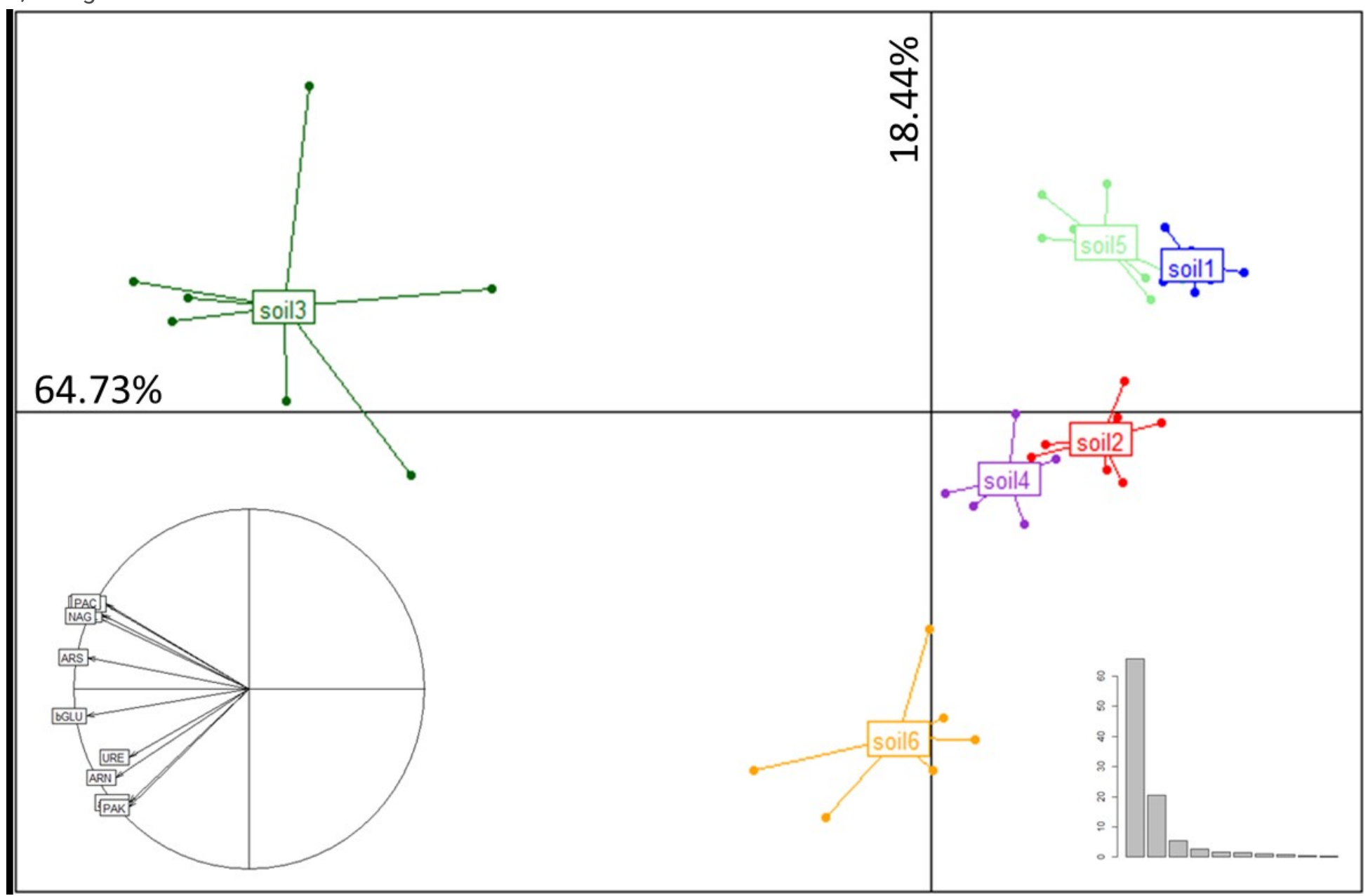




\section{Figure 3}

PCA of the results from the measurement of the 10 enzymatic activities in 6 soils by the 7 selected laboratories. Blue cluster: soil 1; red cluster: soil 2; dark green cluster: soil 3; purple cluster: soil 4; light green cluster: soil 5; orange cluster: soil 6. 